\title{
Pesticide Recordkeeping Form for Florida Applicators ${ }^{1}$
}

\author{
Frederick M. Fishel ${ }^{2}$
}

The purpose of this document is to provide a form containing the required elements to log into a record of pesticide application that meets the restricted use pesticide and Worker Protection Standard (WPS) requirements. An example application record and an explanation of the required elements is provided (Table 3). This form is not required because other methods to keep records, such as handwritten notes, electronic records, and other recordkeeping software systems, are also acceptable if they contain the required information.

\section{What are the recordkeeping requirements for restricted} use pesticides? The 1990 Farm Bill requires private certified pesticide applicators to keep records of all applications of federally restricted use pesticides. These records must be kept for $\mathbf{2}$ years. However, you may want to keep them longer for reference in making future pest management decisions. Although applicators have 14 days to record information for restricted use applications (not associated with WPS), it is a good idea to fill out the recordkeeping form as soon as possible after application to be sure that you have an accurate and detailed record. If you hire a commercial applicator to apply a restricted use pesticide, you should obtain the necessary recordkeeping information from him/her. Commercial applicators are required to provide their clients with a copy of this record within 30 days of application. Application information is also required for fields receiving spot treatments. More details may be found here: https://edis.ifas.ufl.edu/pi012.

What are the recordkeeping requirements for the WPS? The WPS is a federal regulation intended to reduce the risk of pesticide poisoning and injury among agricultural workers. Private applicators who hire pesticide handlers and/or workers must display application information and the Safety Data Sheet (SDS) for each applied product in a centrally located area accessible to all employees within 24 hours of the pesticide application and before workers enter that area. Both must be displayed for 30 days after the restricted entry interval (REI) expires. This display of information applies to all pesticides with the "Agricultural Use Requirements" box printed on the label, not just restricted use pesticides. Once records are removed from the central posting area, they must be kept, along with the SDS, for $\mathbf{2}$ years from the end of the REI. More information on the WPS is available through EDIS at https://edis.ifas.ufl. edu/topic_wps/.

What are the required elements that must be entered into an application record and are there differences according to these two regulations? There are some common elements, but several slight differences between the regulations do exist. They are summarized in Table 1.

1. This document is PI280, one of a series of the Agronomy Department, UF/IFAS Extension. Original publication date June 2019. Visit the EDIS website at https://edis.ifas.ufl.edu for the currently supported version of this publication.

2. Frederick M. Fishel, professor, Agronomy Department, and director, Pesticide Information Office; UF/IFAS Extension, Gainesville, FL 32611.

The use of trade names in this publication is solely for the purpose of providing specific information. UF/IFAS does not guarantee or warranty the products named, and references to them in this publication do not signify our approval to the exclusion of other products of suitable composition. Use pesticides safely. Read and follow directions on the manufacturer's label. All chemicals should be used in accordance with directions on the manufacturer's label.

The Institute of Food and Agricultural Sciences (IFAS) is an Equal Opportunity Institution authorized to provide research, educational information and other services

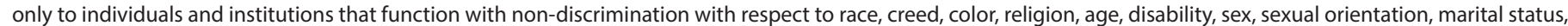

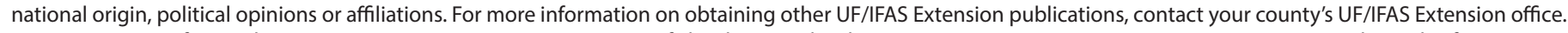
U.S. Department of Agriculture, UF/IFAS Extension Service, University of Florida, IFAS, Florida A \& M University Cooperative Extension Program, and Boards of County Commissioners Cooperating. Nick T. Place, dean for UF/IFAS Extension. 
Can I see an example of a complete record showing both the restricted use pesticide and WPS elements listed correctly? An example is summarized in Table 2 and followed with a brief summary explanation of each element. The information in columns marked with (W) pertain to WPS records and those with an (R) for restricted use pesticides. (RW) signifies that elements are necessary to meet both requirements. Brief explanations of each element are listed following the example record.

What is meant by a "spot treatment" and how should it be recorded? Spot treatments are applications made to less than $1 / 10$ of an acre, such as herbicide treatment along a fencerow. If a spot treatment, record the location of treated site (for example, Johnsongrass along fencerow of Hatchett Creek Field \#3), indicate "spot treatment," and record:

- EPA registration number

- Month, day, year

- Total amount applied

- Brand name

\section{Additional Information}

Aerts, M, O.M Nesheim, and F.M. Fishel. 1998. Pesticide

Recordkeeping. PI-20. Gainesville: University of Florida

Institute of Food and Agricultural Sciences. https://edis.ifas. ufl.edu/pi012

Fishel, F.M., and T. Sanchez. 2006. Worker Protection Standard: Information at a Central Location. PI-112. Gainesville: University of Florida Institute of Food and Agricultural

Sciences. https://edis.ifas.ufl.edu/pi149 
Table 1. Necessary elements for a record according to the restricted use pesticide and WPS recordkeeping requirements.

\begin{tabular}{|c|c|c|}
\hline Required element & Restricted use pesticides & WPS \\
\hline Brand (product) name & $\sqrt{ }$ & $\sqrt{ }$ \\
\hline Common name of the active ingredient & - & $\sqrt{ }$ \\
\hline EPA registration number & $\sqrt{ }$ & $\sqrt{ }$ \\
\hline Total amount of pesticide applied & $\sqrt{ }$ & - \\
\hline Application date & $\sqrt{ }$ & $\sqrt{ }$ \\
\hline Application start/end time & $\sqrt{ }$ & $\sqrt{ }$ \\
\hline Application method & $\sqrt{ }$ & - \\
\hline Address and location/description of treated site & $\sqrt{ }$ & $\sqrt{ }$ \\
\hline Crop/commodity/site treated & $\sqrt{ }$ & $\sqrt{ }$ \\
\hline Size of treated area & $\sqrt{ }$ & - \\
\hline Name of licensed applicator & $\sqrt{ }$ & - \\
\hline License number & $\sqrt{ }$ & - \\
\hline Property owner authorizing application & $\sqrt{ }$ & - \\
\hline REI & - & $\sqrt{ }$ \\
\hline SDS & - & $\sqrt{ }$ \\
\hline $\begin{array}{l}\text { Any record of application made by a non-certified applicator } \\
\text { applying under the supervision of a certified applicator must } \\
\text { include records demonstrating the qualification of the non- } \\
\text { certified applicator }\end{array}$ & $\sqrt{ }$ & - \\
\hline Complete record & Within 14 days of application & $\begin{array}{l}\text { Within } 24 \text { hours of application or } \\
\text { before entry occurs }\end{array}$ \\
\hline Keep record & 2 years & 2 years \\
\hline
\end{tabular}


Table 2. Sample pesticide record meeting requirements for both restricted use pesticides and the WPS.

\begin{tabular}{|c|c|c|c|c|c|c|c|c|}
\hline \multicolumn{9}{|c|}{$\begin{array}{l}\text { of licensed applicator/license nu } \\
\text { authorizing application }{ }^{\left({ }^{(R)} \text { : }\right.}\end{array}$} \\
\hline \multicolumn{9}{|c|}{${ }^{3}$ Field/site location ${ }^{(\mathrm{RW})}$ : Hatchett Creek Field \#3 } \\
\hline \multirow[t]{3}{*}{$\begin{array}{l}{ }^{4} \text { Crop } / \text { site } \\
\text { treated }{ }^{(\mathrm{RW})}\end{array}$} & $\begin{array}{l}{ }^{5} \text { Date } \\
(\mathrm{mo} / \text { day/yr })^{(\mathrm{RW})}\end{array}$ & \multirow[t]{3}{*}{$\begin{array}{l}{ }^{6} \text { Brand } \\
\text { name }{ }^{(\mathrm{RW})}\end{array}$} & \multirow[t]{3}{*}{$\begin{array}{l}{ }^{7} E P A \text { registration } \\
\text { number }{ }^{(\mathrm{RW})}\end{array}$} & \multirow[t]{3}{*}{$\begin{array}{l}{ }^{8} \text { Total amount } \\
\text { applied }^{(\mathrm{R})}\end{array}$} & \multirow{3}{*}{$\begin{array}{l}{ }^{9} \text { Size of } \\
\text { treated } \\
\text { area }^{(R)}\end{array}$} & \multirow[t]{3}{*}{$\begin{array}{l}{ }^{10} \text { Active } \\
\text { ingredient(s) }{ }^{(\mathrm{W})}\end{array}$} & \multirow[t]{3}{*}{${ }^{11} \mathrm{REI}(\mathrm{W})$} & \multirow[t]{3}{*}{$\begin{array}{l}{ }^{12} \text { Application } \\
\text { method }^{(\mathrm{R})}\end{array}$} \\
\hline & Begin time $\mathrm{e}^{(\mathrm{RW})}$ & & & & & & & \\
\hline & End time $\mathrm{e}^{(\mathrm{RW})}$ & & & & & & & \\
\hline \multirow[t]{3}{*}{ Corn } & $3 / 20 / 19$ & AAtrex $4 L$ & $100-497$ & 11 gallons & \multirow[t]{2}{*}{44 acres } & Atrazine & \multirow[t]{3}{*}{12 hours } & \multirow[t]{2}{*}{ Broadcast } \\
\hline & 9:00 AM & Parallel & $66222-87$ & 5.5 gallons & & Metolachlor & & \\
\hline & 1:00 PM & & & & & & & \\
\hline \multirow{4}{*}{\multicolumn{9}{|c|}{$\begin{array}{l}{ }^{1} \text { Record the name of the person who made the application and their license number. } \\
{ }^{2} \text { The name of the person requesting or authorizing the application, or a statement of authority to make such application if the application was } \\
\text { made to property not owned or leased by the licensee. } \\
{ }^{3} \text { Write the location of the site (not farm or business). The site may be identified: } \\
\text { - On a farm map } \\
\text { - As a USDA map and number } \\
\text { - As a Common field name } \\
\text { - As a legal description } \\
\text { If the site is an enclosed space, such as a greenhouse or storage facility, give it a unique name or number. } \\
{ }^{4} \text { Enter the crop, commodity, or site treated. If the location is a greenhouse, record the crop and site location. If treating livestock, record the } \\
\text { type of animals treated (hogs, cattle, etc.). }\end{array}$}} \\
\hline & & & & & & & & \\
\hline & & & & & & & & \\
\hline & & & & & & & & \\
\hline \multirow{2}{*}{\multicolumn{9}{|c|}{$\begin{array}{l}{ }^{5} \text { Enter the month, day, and year in the upper space followed by the time the application began and ended. The end time will determine when } \\
\text { the REl takes effect. }\end{array}$}} \\
\hline & & & & & & & & \\
\hline \multicolumn{9}{|c|}{${ }^{7}$ The EPA registration number is found below the ingredients statement on most labels. } \\
\hline \multicolumn{9}{|c|}{$\begin{array}{l}{ }^{8} \text { This is determined as the rate of product multiplied by the area treated. Record the total quantity of pesticide used, not the quantity after } \\
\text { water or carrier and any adjuvants added. }\end{array}$} \\
\hline \multirow{2}{*}{\multicolumn{9}{|c|}{$\begin{array}{l}{ }^{9} \text { This may be acres, linear feet, bushels, cubic feet, square feet, or number of animals, etc. See note on spot treatments below. } \\
{ }^{10} \text { The common name of the active ingredient(s) is found in the ingredients section of the label. } \\
{ }^{11} \text { For products that fall within the scope of the WPS, the REl is listed in the Agricultural Use Requirements box on the product label. If a tank- } \\
\text { mix is applied with pesticides having different REls, write down the longest REl. }\end{array}$}} \\
\hline & & & & & & & & \\
\hline \multicolumn{9}{|c|}{$\begin{array}{l}{ }^{12} \text { The application method is a requirement of the Florida Department of Agriculture and Consumer Services (FDACS) that fall under Chapter } \\
487 \text { (agricultural uses). It may be listed using general terms such as "broadcast" or "band.." }\end{array}$} \\
\hline
\end{tabular}




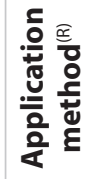

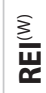
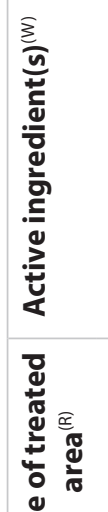

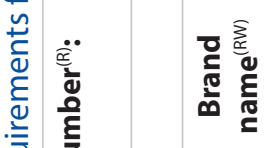

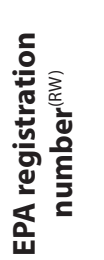

蒙

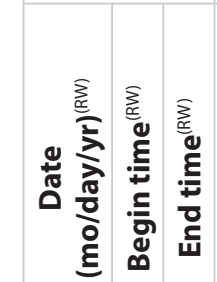

